\title{
Effects of clay materials and moisture levels on habitat preference and survivorship of Formosan subterranean termite, Coptotermes formosanus Shiraki (Blattodea: Rhinotermitidae)
}

\author{
Zhengya Jin $^{1}$, Jian Chen ${ }^{2}$, Xiujun Wen ${ }^{1}$, Cai Wang ${ }^{\text {Corresp. } 1}$ \\ ${ }^{1}$ Guangdong Key Laboratory for Innovation Development and Utilization of Forest Plant Germplasm,College of Forestry and Landscape Architecture, \\ South China Agricultural University, Guangzhou, Guangdong, China \\ 2 Biological Control of Pests Research Unit, Agricultural Research Service, United States Department of Agriculture, Stoneville, Mississippi, United states of \\ American \\ Corresponding Author: Cai Wang \\ Email address: wangcai@scau.edu.cn
}

Formosan subterranean termites, Coptotermes formosanus Shiraki , usually transport clay materials into tree hollows and bait stations. Our previous research showed that $C$. formosanus preferred to aggregate in the locations containing field-collected clay samples, but it was not clear whether this preference was influenced by clay types and/or moisture. In the present study, we conducted multiple-choice tests under low-moisture (25\% moisture) or moderate-moisture (50\% moisture) conditions to evaluate the aggregation and wood-feeding preferences of $C$. formosanus responding to hollow wooden cylinders (simulation of tree hollows) or baiting containers (simulation of bait stations) filled with different clay materials ( bentonite, kaolin, chlorite, illite, or attapulgite), soil, or unfilled. Under low-moisture conditions, the majority of termites were found in the wooden cylinders or baiting containers filled with bentonite. Under moderate-moisture conditions, however, termites preferred to aggregate in wooden cylinders filled with chlorite or attapulgite; the percentages of termites that stayed in baiting containers filled with chlorite, attapulgite or soil were similar, which were significantly higher than those that filled with kaolin, illite, or unfilled. We then conducted no-choice tests to study the effect of clay materials on termites. Under low-moisture conditions, clay filled in the baiting containers significantly increased survivorship and body water percentage (an indicator of termite vigor) of termites, whereas no similar effect was detected under moderatemoisture conditions. This study demonstrated that both clay type and moisture affect termites' preference. 
1 Effects of clay materials and moisture levels on habitat preference and

2 survivorship of Formosan subterranean termite, Coptotermes formosanus

3 Shiraki (Blattodea: Rhinotermitidae)

4

5

6 Zhengya $\operatorname{Jin}^{1}$, Jian Chen $^{2}$, Xiujun Wen ${ }^{1}$, Cai Wang, ${ }^{1, *}$

$7 \quad{ }^{1}$ Guangdong Key Laboratory for Innovation Development and Utilization of Forest Plant

8 Germplasm, College of Forestry and Landscape Architecture, South China Agricultural

9 University, Guangzhou, Guangdong, China.

$10 \quad{ }^{2}$ Biological Control of Pests Research Unit, Agricultural Research Service, United States

11 Department of Agriculture, Stoneville, Mississippi, United States of American.

$13 *$ Correspondence authors:

$14 \quad$ Cai Wang

16 Email address: wangcai@scau.edu.cn 
19 Abstract: Formosan subterranean termites, Coptotermes formosanus Shiraki, usually transport

20 clay materials into tree hollows and bait stations. Our previous research showed that $C$.

21 formosanus preferred to aggregate in the locations containing field-collected clay samples, but it was not clear whether this preference was influenced by clay types and/or moisture. In the present study, we conducted multiple-choice tests under low-moisture (25\% moisture) or moderate-moisture (50\% moisture) conditions to evaluate the aggregation and wood-feeding preferences of $C$. formosanus responding to hollow wooden cylinders (simulation of tree hollows) or baiting containers (simulation of bait stations) filled with different clay materials (bentonite, kaolin, chlorite, illite, or attapulgite), soil, or unfilled. Under low-moisture conditions, the majority of termites were found in the wooden cylinders or baiting containers filled with bentonite. Under moderate-moisture conditions, however, termites preferred to aggregate in wooden cylinders filled with chlorite or attapulgite; the percentages of termites that stayed in baiting containers filled with chlorite, attapulgite or soil were similar, which were significantly higher than those that filled with kaolin, illite, or unfilled. We then conducted no-choice tests to study the effect of clay materials on termites. Under low-moisture conditions, clay filled in the baiting containers significantly increased survivorship and body water percentage (an indicator of termite vigor) of termites, whereas no similar effect was detected under moderate-moisture conditions. This study demonstrated that both clay type and moisture affect termites' preference.

Keywords: soil organism, clay-termite interaction, bentonite, chlorite, attapulgite 


\section{Introduction}

The Formosan subterranean termite, Coptotermes formosanus Shiraki (Blattodea:

Rhinotermitidae), is an economically significant pest distributed in many warm

temperate/subtropical regions of the world, including the United States of America, China, and

Japan (Su, 2003; Austin et al., 2006; Scheffrahn et al., 2015; Chouvenc et al., 2016). Suszkiw

(2000) estimated that the annual repair and control cost of this pest was $\sim 1$ billion dollars in the

United States. C. formosanus damages not only wooden structures, but also live plants (Lai et al.,

1983; Evans et al., 2019). Lai et al. (1983) reported that C. formosanus usually consumed the

xylem, tree vascular tissue that transports water with dissolved minerals from the roots to stems

and leaves and provides physical support as well. Although these trees may appear healthy and

normal (the living part of the tree remained undamaged), they could be easily broken by winds

(Lai et al. 1983). C. formosanus can also damage trunks and roots, which may result in wilt and

sometimes death of the plant (Lai et al., 1983). The impacts of $C$. formosanus on forests had

been largely ignored in the past but have received some attention in recent years. For example,

Evans et al. (2019) reported that 38\% experimental patches of forests around Charleston (South

Carolina, USA) and 42\% patches around New Orleans (Louisiana, USA) were infested by $C$.

formosanus, which caused significantly more and larger tree hollows compared with patches

without termite infestation.

Interestingly, C. formosanus usually transport large amounts of clay and soil into tree holes

and other hollow spaces within/around food (e.g., gaps between bait stations and matrices)

during foraging (Figure 1). Henderson (2008) reported that clay was more preferred than soil for 
61 C. formosanus to fill the void space of tree holes, and a large amount of clay $\left(\sim 1 \mathrm{~m}^{3}\right)$ can be

found in such voids. Wang et al. (2015) found that C. formosanus preferred to aggregate in chambers with field-collected clay. Also, termites preferentially used clay to cover the smooth surface of containers and construct shelter tubes (Wang \& Henderson, 2014; Wang et al., 2015). Xiong et al. (2018a) reported that significantly more C. formosanus and Reticulitermes guangzhouensis Ping aggregated and fed in baiting containers filled with bentonite, a clay mineral, than unfilled containers. In each of these studies, preference of termites to a single source of clay material was investigated and confirmed, but two questions remained unanswered: (1) Do clay types and moisture conditions influence the aggregation and feeding preference by termites? And (2) Do clay materials benefit $C$. formosanus by improving their survival, vigor, and wood feeding?

Based on the structure and mineralogy, clay can be divided into several mineral groups including the montmorillonite/smectite group, kaolin group, chlorite group, illite group, and palygorskite group. In this study, five common clay materials were selected from these groups to investigate their effects on the survival and behavior of C. formosanus (Table 1). Multiple-choice tests were conducted to study the aggregation and wood-feeding preference of $C$. formosanus among different clay materials that were either filled in the hollow wooden cylinders (simulation of tree hollows) or baiting containers (simulation of baiting stations). Also, no-choice tests were conducted to investigate whether each clay material affects the survival, wood-feeding behavior, and vigor (indicated by body water percentage) of termites. All choice and no-choice tests were conducted under low-moisture ( $25 \%$ moisture) conditions that were relatively dry for termites, or 
82

83

moderate-moisture (50\% moisture) conditions that were suitable for termites. Here we did not conduct experiments under high-moisture conditions because termites cannot make tunnels in substrates with extremely high moisture content (Gautam and Henderson, 2011a).

\section{Materials and Methods}

\subsection{Termite Collection and Maintenance}

Underground baiting stations that included 6 pine-wood sticks (without termiticide; $4.5 \times$ $3.0 \times 16.0 \mathrm{~cm}$ ) surrounded by plastic collars (height: $19.5 \mathrm{~cm}$; diameter of upper side: $15.0 \mathrm{~cm}$; diameter of bottom side: $13.5 \mathrm{~cm}$ ) were buried in different locations of the arboretum of South China Agricultural University (SCAU, Guangzhou, China). C. formosanus infestation in each bait station was checked monthly, and the station with large numbers of termites were brought to the laboratory (Xiong et al., 2018a). Three colony groups of $C$. formosanus were collected in November 2018 (for experiments 1 and 2), and two colony groups were collected in May 2019 (for experiment 3). Colonies were over $1 \mathrm{~km}$ apart (Table 2). Collected baiting stations were maintained in the lab in $60 \mathrm{~L}$ plastic storage boxes for $<1$ month $\left(23-27^{\circ} \mathrm{C}\right.$ under darkness). Before the experiment, wood sticks were taken out and gently knocked to extract termites, and the caste distribution of each colony group were determined by counting 100 termites for 5 times (Table 2).

\subsection{Soil and Clay}

Top soil (depth $<5 \mathrm{~cm})$ was collected from a location $\left(23^{\circ} 09^{\prime} 26^{\prime \prime} \mathrm{N}, 113^{\circ} 21^{\prime} 08^{\prime \prime} \mathrm{E}\right)$ in the 
103

104

105

106

107

108

109

110

111

112

113

114

115

116

117

118

119

120

121

122

123

arboretum of SCAU where C. formosanus activities have been detected. A sample of soil was

sent to the Laboratory of Forestry and Soil Ecology (College of Forestry and Landscape

Architecture, SCAU), and identified as sandy loam soil (12\% clay, 21\% silt, and 67\% sand). The

dried soil was ground with a wooden mortar and pestle, and then sifted through a 2-mm sieve to

remove coarse particles and plant roots. Five clay materials, bentonite (Fresh \& Natural ${ }^{\mathrm{TM}}$,

Bentonite Performance Minerals LLC, Houston, USA), kaolin (Jufeng ${ }^{\circledR}$, Shanxi Jufeng Kaolin

Co., Ltd, Jinzhong, China), chlorite (Hetalc ${ }^{\circledR}$, Haicheng Hetalc Powder Technology Co., Ltd,

Haicheng, China), illite (Junhong ${ }^{\circledR}$, Huiyuan Junhong New Material Co., Ltd, Datong, China),

and attapulgite (Dingbang ${ }^{\circledR}$, Dingbang Mineral Products Technology Co., Ltd, Changzhou,

China), were purchased. Sample of clay materials or soil were sent to the Laboratory of

Environmental Chemistry (College of Natural Resources and Environment, SCAU) to measure

chemical properties (i.e., $\mathrm{pH}$, contents of organic matter, total nitrogen, and exchangeable cation,

and cation exchange capacity, as shown in Table 1). Clay and soil were sterilized at $80^{\circ} \mathrm{C}$ for 3

days, and then completely dried at $50^{\circ} \mathrm{C}$ for $>2$ weeks. The formula provided by Chen and

Shelton (2017) was used to determine the moisture content of soil and clay: moisture content (\%)

$=[$ weight of distilled water added / (weight of saturated soil or clay - weight of dried soil or

clay)] $\times 100 \%$. To prepare soil and clay with $25 \%$ - or $50 \%$-moisture, the required amount of

deionized water and dried soil or clay were placed in the zip-lock bags and thoroughly mixed

(Table 1).

2.3 Experiment 1: Preference of Clay Materials Filled in Wooden Cylinders

Peer) reviewing PDF | (2020:06:49998:1:1:NEW 24 Sep 2020) 
and feed in hollow wooden cylinders which were filled with certain clay material or soil, or unfilled. Each test (under either low- or moderate-moisture conditions) was repeated 12 times

127 (each of the three colony groups was repeated 4 times). The bioassay arenas were plastic containers $($ volume $=1250 \mathrm{~mL}$, height $=6 \mathrm{~cm}$, diameter of upper side $=19.2 \mathrm{~cm}$, diameter of bottom side $=16 \mathrm{~cm}$ ). To set the bioassays under low-moisture conditions, $25 \%$-moisture soil

130 (substrate) was added into the container to the depth of $0.5 \mathrm{~cm}$. Hollow wooden cylinders

131 (Schima superba Gardn. et Champ., height $=28 \mathrm{~mm}$, internal diameter $=26 \mathrm{~mm}$, external diameter $=30 \mathrm{~mm}$, thickness of the bottom side $=3 \mathrm{~mm}$, diameter of hole on the bottom side $=$ $16 \mathrm{~mm}$; Fig. 2A) were oven-dried at $80^{\circ} \mathrm{C}$ for 5 days and weighed. Seven wooden cylinders were filled with 25\%-moisture clay materials (bentonite, kaolin, chlorite, illite, or attapulgite) or soil, or unfilled (Fig. 2A). These wooden cylinders were placed on the substrate in the arena with randomly assigned orders, and the adjacent cylinders were equally distanced. Substrate (25\%moisture soil) was then added in the container until the base of cylinders was partially buried in the depth of $1 \mathrm{~cm}$ (Fig. 2B). Similar procedures were carried out to set the bioassays under moderate-moisture conditions, but clay and soil with 50\% moisture were used.

140 Four hundred termites (percentages of workers and soldiers were determined by the caste distribution of each colony group as shown in Table 2) were counted and released into the center of each arena. The containers were sealed with plastic wrap to keep the internal moisture conditions and maintained in a $25^{\circ} \mathrm{C}$ environmental chamber under total darkness. At the end of 
145

146

147

cylinder or substrate (none of the termites stayed on the outer wall of the wooden cylinders or on the surface of the substrate). The wooden cylinders were carefully washed using distilled water to remove any particles, and placed in an oven $\left(80^{\circ} \mathrm{C}\right)$ for 5 days and weighed. The dry weight change of wooden cylinders before and after the experiment was measured to calculate wood consumption.

\subsection{Experiment 2: Preference of Clay Materials Filled in Baiting Containers}

The protocols of multiple-choice tests provided by Xie et al. (2019a) were modified to investigate whether C. formosanus prefer to aggregate and feed in the baiting containers filled with each clay material or soil, or unfilled. Each choice-test (under either low- or moderatemoisture conditions) was repeated 12 times (each of the three colony groups was repeated 4 times). The bioassay arena was a $1250 \mathrm{~mL}$ plastic container as mentioned earlier. The baiting container was plastic box (height $=33 \mathrm{~mm}$; diameter of upper side $=41 \mathrm{~mm}$, diameter of bottom side $=31 \mathrm{~mm})$ with 10 holes $(5 \mathrm{~mm}$ in diameter, staggered distributed in two rows $)$ drilled on the wall (Fig. 3A). A pine wood block $(20 \times 20 \times 20 \mathrm{~mm})$ was completely dried in an $80^{\circ} \mathrm{C}$ oven for 5 days and weighed, and then placed into the box (Fig. 3A). Under low-moisture conditions, the void space of seven baiting containers was either filled with 25\%-moisture clay (bentonite, kaolin, chlorite, illite, or attapulgite) or soil (Fig. 3B), or unfilled. These baiting containers were placed in the bioassay arenas with randomly assigned orders. Each baiting container was equally distanced with the adjacent ones. Substrate (25\%-moisture soil) was then added until the baiting containers were buried (Fig. 3C). We carried out similar procedures to set the choice test under 
166

167

168

169

moderate-moisture conditions, but clay and soil at the 50\%-moisture level were used.

Four hundred termites were released into the center of each arena. The bioassay arenas were sealed with plastic wraps and placed in the environmental chamber $\left(25^{\circ} \mathrm{C}\right.$ and under total darkness). At the end of the experiment (day 21), the number of live termites stayed within each baiting container or substrate was counted. The wood consumption was measured as mentioned earlier. The formula provided by Xie et al. (2019a) was used to calculate the moisture content of wood blocks: wood moisture $(\%)=[($ wet weight of wood block after the experiment - dry weight of wood block after the experiment) / dry weight of wood block after the experiment] $\times$ $100 \%$.

\subsection{Experiment 3: Effect of Clay Materials on Survival, Vigor, and Wood Consumption of}

\section{Termites}

The protocols of no-choice tests provided by Xie et al. (2019a) were modified to investigate the survival, body water percentage (an indicator of termite vigor), and wood consumption of termites, as well as wood moisture when the baiting containers (as mentioned in experiment 2) were filled with each clay material (bentonite, kaolin, chlorite, illite, or attapulgite) or soil, or unfilled. The tests were conducted under either low-moisture (25\% moisture) or moderatemoisture $(50 \%$ moisture) conditions. In total, the tests contained 14 treatments, and each treatment was repeated 10 times (each of the two colony groups was repeated 5 times).

To set the bioassays under low-moisture conditions, a baiting container (either filled with 25\%-moisture bentonite, kaolin, chlorite, illite, attapulgite, soil or unfilled) was placed in the 
187 188

center of a plastic box (volume $=300 \mathrm{~mL}$, height $=62 \mathrm{~mm}$; diameter of upper side $=86 \mathrm{~mm}$, diameter of bottom side $=66 \mathrm{~mm})$. Substrate $(25 \%$-moisture soil $)$ was then added into the plastic box until the bating container was buried. The same procedure was conducted to set the bioassays under moderate-moisture conditions, but 50\%-moisture soil or clay materials were used.

One hundred termites were counted and released into the center of each box. The bioassays were sealed with plastic wraps and placed in a completely dark environment chamber at $25^{\circ} \mathrm{C}$. The survivorship of termites was recorded at the end of the experiment (day 21). Body water percentage of termites were measured as previously described in Xie et al. (2019a). Specifically, 10 workers were randomly selected, and their fresh weight was measured using a $0.1 \mathrm{mg}$ electronic balance. These termites were then placed in an oven $\left(50^{\circ} \mathrm{C}\right)$ for 3 days, and their dry weights were measured using the same electronic balance. The formula provided by Xie et al. (2019a) was used to calculate the body water percentage of termites: body water percentage (\%) $=[($ fresh weight of termites - dry weight of termites $) /$ fresh weight of termites $] \times 100 \%$. The wood consumption and wood moisture were also measured and calculated as mentioned above.

\subsection{Data Analysis}

For each multiple-choice test in the experiments 1 and 2, the percentage of termites that aggregated in each wooden cylinders or baiting containers (filled with bentonite, kaolin, chlorite, illite, attapulgite, soil, or unfilled), or stayed within the substrate was calculated. Because of the sum constraint of the percentage data, we applied log-ratio transformation mentioned by Kucera 
208

209

210

211

212

213

214

215

216

217

218

219

220

221

222

223

224

225

226

227

228

and Malmgren (1998) to make the raw percentages data independent. Two-way analysis of variance (ANOVA, SAS 9.4, SAS Institute, Cary, NC) was used to analyze the transformed data with termite colony as the random factor and aggregation site as the fixed factor. In addition, we compared wood consumption and wood moisture using the two-way ANOVA with termite colony as a random factor and filling types (filled with different clay materials or soil or remained unfilled) as a fixed factor. For no-choice tests in the experiments 3, we compared the survivorship, body water percentage, and wood consumption of termites, as well as wood moisture, using a two-way ANOVA with termite colony as the random factor and treatment as the fixed factor. Tukey's Honest Significant Difference (HSD) test was used after each ANOVA for post-hoc comparisons. In all tests, the significance levels were determined at $\alpha=0.05$.

\section{Results}

\subsection{Experiment 1: Preference of Clay Materials Filled in Wooden Cylinders}

Under low-moisture conditions, low survivorship $(<30 \%)$ of termites were found in the colony group 1 . As a result, only data obtained from the colony groups 2 and 3 (survivorship $\geq$ $70 \%$ ) were analyzed. Similar percentages of termites aggregated in the substrate and wooden cylinders filled with bentonite, both were significantly higher than that in other locations (Fig. 4A). No significant difference in wood consumption was detected when compared among wooden cylinders filled with each clay material or soil, or unfilled (Fig. 4B).

Under moderate-moisture conditions, data obtained from the three termite colonies were analyzed. Similar percentages of termites were found in the wooden cylinders filled with 
229

230

231

232

233

234

235

236

237

238

239

240

241

242

243

244

245

246

247

248

249

attapulgite and chlorite, and both were significantly higher than that of wooden cylinders filled with kaolin, illite, or soil, or unfilled (Fig. 5A). However, wood consumption was similar when compared among filling types (Fig. 5B).

\subsection{Experiment 2: Preference of Clay Materials Filled in Baiting Containers}

Under low-moisture conditions, low survivorship $(<30 \%)$ of termites were found in the colony group 1, and therefore only data obtained from colony groups 2 and 3 (survivorship $\geq$ $70 \%$ ) were analyzed. Most termites were found in the baiting containers filled with bentonite, whereas only a few termites were found in other locations (Fig. 6A). The wood consumption in the baiting containers filled with bentonite was also significantly higher than the other ones (Fig. 6B). The wood moisture was similar when compared among different filling types (Fig. 6C). Under moderate-moisture conditions, data obtained from the three termite colonies were analyzed. Similar percentages of termites were found in the baiting containers filled with attapulgite, chlorite, or soil, which were significantly higher than that of containers filled with kaolin or illite, or unfilled (Fig. 7A). The wood consumption was not significantly different among filling types (Fig. 7B), but wood moisture in baiting containers filled with bentonite was significantly higher than other ones (Fig. 7C).

\subsection{Experiment 3: Effect of Clay Materials on Survival, Vigor, and Wood Consumption of}

\section{Termites}

Under low-moisture conditions, treatments with clay materials had significantly higher 
250

251

252

253

254

255

256

257

258

259

260

261

262

263

264

265

266

267

268

269

270

termite survivorship compared to the treatment with unfilled baiting containers (Fig. 8A). Also, clay significantly increased body water percentage of termites compared to the treatment with soil-filled baiting containers under low-moisture conditions (Fig. 8B). No significant difference in survivorship and body water percentage of termites were detected among treatments under moderate-moisture conditions (Figs. 8A and 8B). Termites consumed least wood when baiting containers were filled with kaolin under low-moisture conditions, whereas the highest wood consumption was found when baiting containers were unfilled under moderate-moisture conditions (Fig. 8C). The wood moisture was significantly higher when the baiting containers were filled with bentonite, attapulgite, or chlorite (under moderate-moisture conditions) compared with the remained treatments (Fig. 8D).

\section{Discussion}

Many previous studies focused on clay preference and utilization by the higher fungusgrowing termites in the family Termitidae. The biological functions of these termites as soil engineers have been reviewed by Bignell (2006), Pardeshi and Prusty (2010), and Jouquet et al. (2011, 2016). Jouquet et al. (2011) pointed out that higher termites transport large amounts of clay from various depths in underground sites to the soil surface. After they use clay to construct the aboveground biostructures such as sheetings and mounds, the subsequent erosion processes would modify the physical and chemical properties of surface soil, which may exert a significant impact on the ecosystems (Jouquet et al., 2011; 2016). For example, Harit et al. (2015) reported that the fungus-growing termite Hypotermes obscuriceps (Wasmann) constructed extensive 
271 sheetings on their food (leaves and branches), and when sheetings were degraded by rain a lot of

272 inorganic ions (e.g., $\mathrm{K}^{+}, \mathrm{F}^{-}$, and $\mathrm{Cl}^{-}$) were released and therefore impacted soil properties. Sileshi

273 et al. (2010) reported that mounds constructed by termites (e.g., species in the genus

274 Ancistrotermes, Macrotermes, Odontotermes, Cubitermes, and Trinervitermes) were enriched in

275 clay and nutrition, thus creating "islands of fertility" and enhancing the growth of plants, which

276 shaped the spotted vegetation patterns in savannas across Africa. Bonachela et al. (2015)

277

278

279

280

281

282

283

284

285

286

287

288

289

290

291

reported that such spotted vegetation patterns created by termites made the landscapes more

robust to aridity and more stabilized to global climate changes. Likewise, Evans et al. (2011)

reported that in the arid climate zones where earthworms are absent, termites provide alternative ecological services to improve water infiltration and soil nitrogen, and therefore contributed to the sustainability of dryland agriculture.

Compared to higher termites, much less attention has been paid to the potential interactions among clay, lower subterranean termites, and ecosystems. Harit et al. (2017) reviewed 29 articles about soil sheeting (always enriched in clay) produced by termites, and only 2 of them focused on the sheeting behaviors of lower subterranean termites, Psammotermes allocerus Silvestri (Vlieghe et al., 2015) and Coptotermes acinaciformis (Froggatt) (Oberst et al. 2016, 2019).

Vlieghe et al. (2015) observed a high level of soil or sand sheeting on grasses during the early formation stages of Namibian fairy circles constructed by P. allocerus. In contrast, the lowest number of termites and sheet grasses can be detected in the mature circles, which indicates that termites abandon their ephemeral polycalic nests within the mature circle (Vlieghe et al., 2015).

Oberst et al. (2019) reported that $C$. acinaciformis performed clay-sheeting behaviors for 
292

293

294

295

296

297

298

299

300

301

302

303

304

305

306

307

308

309

310

311

312

different purposes according to the situational context. When the wood was unloaded, $C$.

acinaciformis wrapped the dry wood with a layer of clay to increase its moisture levels.

However, when the wood was loaded, C. acinaciformis kept the wood dry to improve its compressive strength and rigidity; meanwhile, they substituted some of the wood for clay walls to improve the bearing capacity. Some previous studies showed that C. formosanus also transported clay to fill the void volumes within tree holes or bait stations (Henderson, 2018). Such behaviors may result from tunnel excavation and subsequent transport processes ( $\mathrm{Li}$ et al., 2008; Lee et al., 2020). Some evidence also showed that these behaviors may be important for the foraging of lower subterranean termites because they preferred to aggregate and feed on food which was artificially covered/filled with clay (Wang \& Henderson, 2014; Wang et al., 2015;

Xiong et al., 2018a).

Previous studies showed that moisture conditions of substrates are important for the survival of subterranean termites (Sponsler \& Appel, 1990; Cornelius \& Osbrink, 2010; Gautam \& Henderson, 2015). For example, Cornelius and Osbrink (2010) reported that C. formosanus contacted with dry soil had high mortality caused by desiccation. Gautam and Henderson (2015) reported that C. formosanus individuals showed three stages of desiccation - curling of antennae (stage I), on back but can right themselves and walk (stage II), and unable to get off back (stage III) - soon after exposed to open-air conditions, and most termites were destined to die once they reached stage III. Also, Gautam and Henderson (2015) reported a colony-level variation in the rate of water loss, since termites from one colony dried out faster than that from other colonies. Similarly, one of the three termite colonies used in our choice tests had a high mortality rate 
313 under low-moisture conditions, probably due to the low drought-tolerance of this colony.

314 Interestingly, Gautam and Henderson (2015) showed that termites in the groups $(\mathrm{n}=50)$ had a

315 slower desiccation rate than the individual ones, and suggested that the large densities of field

316 colonies of $C$. formosanus may contribute to maintaining high humidity levels and reducing

317 water loss. One potential limitation of our studies is that we used only 400 termites in each

318 replicate of the choice tests, and this relatively low density of termites may have an effect on the

319 moisture-maintaining capacity and behaviors of termites, especially under low-moisture

320

321

322

conditions. Future experiments with larger groups of termites would be helpful.

Our no-choice tests showed that all types of clay materials significantly increased body water percentage, an important indicator of termite vigor (Arquette et al., 2006), compared with soil under low-moisture conditions (Fig. 8B). This probably occurred because clay can retain more water than soil (as shown in Table 1), and created a more favorable microenvironment in the baiting containers. To avoid desiccation, $C$. formosanus has a strong tendency to aggregate in locations with proper humidity/moisture levels (Nakayama et al., 2005; Gautam \& Henderson, 2011a, 2011b, 2011c). However, they do not prefer substrate and wood with extremely high moisture content (Nakayama et al., 2005; Gautam \& Henderson 2011a). Our choice tests showed that the majority of termites stayed in the wooden cylinders or baiting containers filled with bentonite under low-moisture conditions (Figs. 4 and 6). Such preference was moisturedependent, because no significant termite aggregation was detected responding to the $50 \%$ moisture bentonite. It is probable that termites can acquire enough water under moderatemoisture conditions. Therefore, it is not necessary to stay within bentonite to maintain moisture. 
334 Also, bentonite can absorb a large amount of water at the 50\%-saturation level (Table 1), and

335 caused much higher wood moisture compared with other clay materials or soil (Figs. 7C and

336 8D), which may inhibit the feeding activities of $C$. formosanus. Likewise, Carey et al. (2019)

337 reported that the mound-building termites, Macrotermes michaelseni (Sjöstedt), performed

338 different clay-relocation behaviors depending on the humidity levels, as they transport less soil

339 and creates structures with smaller volumetric envelopes in the laboratory with low ambient

340 humidity compared with high-humidity conditions.

341 The present study focused on the clay preference by termites under different moisture

342 conditions. There may be other factors affecting termite behaviors in response to clay materials.

343 For example, previous research showed that the lower subterranean termites Reticulitermes

344 flavipes (Kollar) can detect certain ions in soil (Botch \& Judd, 2011), and directly acquire

345 micronutrients such as calcium, magnesium, iron, and manganese from the soil (Janzow \& Judd,

346 2015). Our choice tests showed that termites tended to aggregate in wooden cylinders and baiting

347 containers filled with attapulgite and chlorite under moderate-moisture conditions. These clay

348 materials have high contents of exchangeable cations of calcium and magnesium (Table 1),

349 which may result in the termite aggregation. In addition, previous studies showed that soil microbes such as Metarrhizium anisopliae (Metschn.) Sorok and Trichoderma fungi significantly influenced the aggregation and tunneling preferences of subterranean termites

(Xiong et al., 2018b; 2019; Wen et al., 2020). In our study, different microbes may colonize wooden cylinders or baiting containers containing each clay material and soil, and affect termites' choice. Also, clay may have more biological functions for termites besides creating a 
355

356

357

358

359

360

361

362

363

364

365

366

367

368

369

370

371

372

373

moist environment and preventing termites from desiccation. For example, many social insects

cover/fill food sources with various materials (e.g., soil particles) to block competitors and

predators (e.g., Maciel et al., 2015; Mendonça et al., 2019; Qin et al., 2019). Chouvenc et al.

(2015) reported that when $C$. formosanus encountered its predator, the big-headed ant, Pheidole

megacephala (Fabr.), termites immediately deposited particles and sealed the access point of ants

to "create a physical separation with little to no casualties". Clay materials in the void spaces

may also protect termites from being exposed to the open-air environment and attacked by ants

and other predators. One limitation of our study is that we only tested five clay materials, and

many other clay or silt minerals may also affect aggregation and foraging behaviors of $C$.

formosanus. It would be valuable to conduct choice and no-choice tests with more clay and silt

materials in the future.

Baiting is one of the main methods to suppress and eliminate populations of subterranean

termites (Evans \& Iqbal, 2015; Su, 2019), but termites showed a low tendency to attack bait with

low moisture levels (Cornelius \& Osbrink, 2011). Our previous studies tried to create a

microhabitat more suitable for termites by adding super absorbent polymers into bait stations.

Although these water-retaining materials increased bait consumption, they did not cause

significant aggregation by termites, probably because super absorbent polymers are gel-like and

therefore termites cannot make tunnels to access the bait matrices (Xie et al., 2019a, 2019b). The

present study showed that bentonite filled in the baiting containers not only caused aggregation

of termites but also increased wood consumption under low-moisture conditions (Fig. 6A). This

result indicated that placing bentonite in bait stations may increase termite infestation and bait

Peer] reviewing PDF | (2020:06:49998:1:1:NEW 24 Sep 2020) 
376

377

378

379

380

381

382

383

consumption in drought locations. However, it is worth noting that moisture levels in reality may

vary locally and fluctuate over time. Also, multiple environmental factors may influence

termites' choice in the field. It is important to conduct field studies to confirm whether bentonite can potentially be used as termite attractants under natural conditions.

\section{Conclusion}

In this study, we discovered that termites preferred to aggregate in wooden cylinders or baiting containers filled with bentonite compare with other clay materials (kaolin, chlorite, illite, and attapulgite) under low-moisture conditions. Also, termite consumed significantly more wood in the baiting containers filled with bentonite. Under moderate-moisture conditions, however, chlorite and attapulgite were most preferred by termites. In addition, no-choice tests showed that baiting containers filled with clay materials increased termite survivorship and body water percentage (an indicator of termite vigor) under low-moisture conditions. This study showed that both clay types and moisture are important for the survival and foraging activities of termites, and can influence their aggregation and wood-feeding preferences.

\section{Acknowledgments}

We sincerely thank Dr. Eric Riddick, Dr. Ilaria Negri (the editor), and three reviewers for their valuable comments and suggestions on the manuscript. We also thank Wenquan Qin (College of Forestry and Landscape Architecture, SCAU, Guangzhou, China) for providing the picture (Fig. 1A) used in this manuscript. 
References

Arquette TJ, Champagne DE, Brown MR, Forschler BT. 2006. Evaluation of novel and traditional measures for vigor of laboratory-cultured termites, Reticulitermes flavipes (Kollar). Journal of Insect Physiology 52: 51-66 DOI 10.1016/j.jinsphys.2005.09.003.

Austin JW, Szalanski AL, Scheffrahn RH, Messenger MT, McKern JA, Gold RE. 2006. Genetic evidence for two introductions of the Formosan subterranean termite, Coptotermes formosanus (Isoptera: Rhinotermitidae), to the United States. Florida Entomology 89: 183193 DOI 10.1653/0015-4040(2006)89[183:geftio]2.0.co;2.

Bignell DE. 2006. Termites as soil engineers and soil processors. In: Konig H, and Varma A, eds . Soil Biology: Springer-Verlag Berlin, Berlin, Germany, pp. 183-220.

Bonachela JA, Pringle RM, Sheffer E, Coverdale TC, Guyton JA, Caylor KK, Levin, SA, Tarnita CE. 2015. Termite mounds can increase the robustness of dryland ecosystems to climatic change. Science 347: 651-655 DOI 10.1126/science.1261487.

Botch PS, Judd TM. 2011. Effects of Soil Cations on the Foraging Behavior of Reticulitermes fla vipes (Isoptera: Rhinotermitidae). Journal of Economic Entomology 104: 425-435 DOI 10.1603/ec10118

Carey NE, Calovi DS, Bardunias P, Turner JS, Werfel J. 2019. Differential construction response to humidity by related species of mound-building termites. Journal of Experimental Biology 222: No.212274 DOI 10.1242/jeb.212274

Chen M, Shelton AM. 2017. Impact of soil type, moisture, and depth on swede midge (Diptera: 

10.1093/ee/36.6.1349.

420

421

422

423

424

425

426

427

428

429

430

431

432

433

434

435

436

437

438

Chouvenc T, Mullins AJ, Su NY. 2015. Territorial status-quo between the big-headed ant

(Hymenoptera: Formicidae) and the Formosan subterranean termite (Isoptera:

Rhinotermitidae). Florida Entomology 98: 157-161 DOI 10.1653/024.098.0127.

Chouvenc T, Scheffrahn RH, Su NY. 2016. Establishment and spread of two invasive subterranean termite species (Coptotermes formosanus and C. gestroi; Isoptera: Rhinotermitidae) in metropolitan southeastern Florida (1990-2015). Florida Entomology 99: 187-192 DOI 10.1653/024.099.0205.

Cornelius ML, Osbrink WLA. 2010. Effect of soil type and moisture availability on the foraging behavior of the Formosan subterranean termite (Isoptera: Rhinotermitidae). Journal of Economic Entomology 103:799-807 DOI 10.1603/EC09250.

Cornelius ML, Osbrink WLA. 2011. Effect of seasonal changes in soil temperature and moisture on wood consumption and foraging activity of Formosan subterranean termite (Isoptera: Rhinotermitidae). Journal of Economic Entomology 104: 1024-30 DOI 10.1603/EC10332.

Evans TA, Dawes TZ, Ward PR, Lo N. 2011. Ants and termites increase crop yield in a dry climate. Nature Communications 2: 262 DOI 10.1038/ncomms1257.

Evans TA, Forschler BT, Trettin CC. 2019. Not just urban: The Formosan subterranean termite, Coptotermes formosanus, is invading forests in the Southeastern USA. Biological Invasions 21: 1283-1294 DOI 10.1007/s10530-018-1899-5.

Evans TA, Iqbal N. 2015. Termite (order Blattodea, infraorder Isoptera) baiting 20 years after 
commercial release. Pest Managment Science 71: 897-906 DOI 10.1002/ps.3913.

440 Gautam BK, Henderson G. 2011a. Effects of sand moisture level on food consumption and

441 distribution of Formosan subterranean termites (Isoptera: Rhinotermitidae) with different soldier proportions. Journal of Entomological Sciences 46: 1-13 DOI 10.18474/0749-800446.1.1.

Gautam BK, Henderson G. 2011b. Wood consumption by Formosan subterranean termites

Harit A, Moger H, Duprey JL, Gajalakshmi S, Abbasi SA, Subramanian S, Jouquet P. 2015. Termites can have greater influence on soil properties through the construction of soil sheetings than the production of above-ground mounds. Insectes Sociaux 64: 247-253 DOI 10.1007/s00040-017-0541-3.

Harit A, Shanbhag R, Chaudhary E, Cheik S, Jouquet P. 2017. Properties and functional impact of termite sheetings. Biology and Fertility of Soils 53: 743-749 DOI 10.1007/s00374-017- 
Henderson G. 2008. The termite menace in New Orleans: did they cause the floodwalls to tumble? American Entomologist 54: 156-162 DOI 10.1093/ae/54.3.156.

Janzow MP, Judd TM. 2015. The termite Reticulitermes flavipes (Rhinotermitidae: Isoptera) can acquire micronutrients from soil. Environmental Entomology 44: 814-820 DOI 10.1093/ee/nvv041.

Jouquet P, Bottinelli N, Shanbhag RR, Bourguignon T, Traoré S, Abbasi SA. 2016 Termites: the neglected soil engineers of tropical soils. Soil Science 181: 157-165.

Jouquet P, Traoré S, Choosai C, Hartmann C, Bignell D. 2011. Influence of termites on

Kucera M, Malmgren BA. 1998. Logratio transformation of compositional data: A resolution of 8398(97)00047-9.

Lai PY, Tamashiro M, Yates JR, Su NY, Fujii JK, Ebesu RH. 1983. Living plants in Hawaii

Lee SB, Su NY, Song HS, Lee SH. 2020. Minimizing moving distance in deposition behavior of the subterranean termite. Ecology and Evolution 10: 4 DOI 10.1002/ece3.6051. termite (Isoptera: Rhinotermitidae). Annals of the Entomological Society of America 101: 
456- 462 DOI 10.1603/008.102.0216.

482

483

484

485

486

487

488

489

490

491

492

493

494

495

496

497

498

499

500

501

Maciel TT, Castro MM, Barbosa BC, Fernandes EF, Santos-Prezoto HH, Prezoto F. 2015.

Foraging behavior of fire ant Solenopsis saevissima (Smith) (Hymenoptera, Formicidae) in Felis catus Linnaeus (Carnivora, Felidae) carcass. Sociobiology 62: 610-612 DOI 10.13102/sociobiology.v62i4.736.

Mendonça R, Santos-Prezoto HH, Prezoto F. 2019. Actions of the fire ant Solenopsis saevissima (Smith) (Hymenoptera: Formicidae) on a big-eared opossum carcass. Florida Entomology 102: 435-437 DOI 10.1653/024.102.0224.

Nakayama T, Yoshimura T, Imamura Y. 2005. Feeding activities of Coptotermes formosanus Shiraki and Reticulitermes speratus (Kolbe) as affected by moisture content of wood. Journal of Wood Science 51: 60-65 DOI 10.1007/s10086-003-0612-0.

Oberst S, Lai JC, Evans TA. 2016. Termites utilise clay to build structural supports and so increase foraging resources. Scientific Reports 6: No. 20990 DOI 10.1038/srep20990.

Oberst S, Lenz M, Lai JCS, Evans TA. 2019. Termites manipulate moisture content of wood to maximize feeding. Biology Letters 15: No. 20190365. DOI 10.1098/rsb1.2019.0365.

Pardeshi M, Prusty BAK. 2010. Termites as ecosystem engineers and potentials for soil restoration. Current Science 99: 11 DOI 10.1371/journal.pone.0011405.

Qin W, Chen X, Hooper-Bùi LM, Cai J, Wang L, Sun Z, Wen X, Wang C. 2019. Food-burying behavior in red imported fire ants (Hymenoptera: Formicidae). PeerJ 7: No. e6349 DOI 10.7717/peerj.6349.

Scheffrahn RH, Carrijo TF, Křeček J, Su NY, Szalanski AL, Austin JW, Chase JA, Mangold JR. 
502

503

504

505

506

507

508

509

510

511

512

513

514

2015. A single endemic and three exotic species of the termite genus Coptotermes (Isoptera, Rhinotermitidae) in the New World. Arthropod Systematics \& Phylogeny 73: 333-348.

Sileshi GW, Arshad MA, Konaté S, Nkunika PO. 2010. Termite-induced heterogeneity in African savanna vegetation: mechanisms and patterns. Journal of Vegetation Science 21: 923-937 DOI 10.1111/j.1654-1103.2010.01197.x.

Sponsler RC, Appel AG. 1990. Aspects of the water relations of the Formosan and eastern subterranean termites (Isoptera: Rhinotermitidae). Environmental Entomology 19: 15-20 DOI 10.1093/ee/19.1.15.

Su NY. 2003. Overview of the global distribution and control of the Fornmosan subterranean termite. Sociobiology 41: 7-16 DOI 10.1520/STP11123S.

Su NY. 2019. Development of baits for population management of subterranean termites. Annual Review of Entomology 64: 115-130 DOI 10.1146/annurev-ento-011118-112429.

Suszkiw J. 2000. Taking aim at Formosan subterranean termites. Agriciltural Reseach 48: 12-15.

Vlieghe K, Picker M, Ross-Gillespie V, Erni B. 2015. Herbivory by subterranean termite colonies and the development of fairy circles in SW Namibia. Ecological Entomology 40: 42-49 DOI 10.1111/een.12157.

Wang C, Henderson G, Gautam BK. 2015. Behavioral response of Formosan subterranean termites (Isoptera: Rhinotermitidae) to soil with high clay content. Journal of Insect Behavior 28: 303-311 DOI 10.1007/s10905-015-9505-5.

Wang C, Henderson G. 2014. Clay preference and particle transport behavior of Formosan subterranean termites (Isoptera: Rhinotermitidae): a laboratory study. Insect Science 21: 
524

525

526

527

528

529

530

531

532

533

534

535

536

537

538

539

540

541

542

543

Wen C, Xiong H, Wen J, Wen X, Wang C. 2020. Trichoderma species attract Coptotermes formosanus and antagonize termite pathogen Metarhizium anisopliae. Frontiers in Microbiology 11: No. 653 DOI 10.3389/fmicb.2020.00653.

Xie Q, Xiong H, Qin W, Wen X, Sun Z, Wang C. 2019a. Effect of polyacrylamide/attapulgite composite on foraging behaviors of Formosan subterranean termites (Blattodea: Rhinotermitidae). Journal of Economic Entomology 112: 290-299 DOI 10.1093/jee/toy332.

Xie Q, Jin Z, Lin W, Xue K, Chen X, Zhao K, Wen X, Wang C. 2019b. Super absorbent polymers buried within dry soil attract Formosan subterranean termites (Blattodea: Rhinotermitidae). Forests 10: No. 591 DOI 10.3390/f10070591.

Xiong H, Cai J, Chen X, Liang SP, Wen X, Wang C. 2019. The effects of Trichoderma fungi on tunneling, aggregation, and colony-initiation preferences of black-winged subterranean termites, Odontotermes formosanus (Blattodea: Termitidae). Forests. 10: No. 1020. DOI $10.3390 / \mathrm{f} 10111020$.

Xiong H, Qin W, Wen X, Sun Z, Wang C. 2018a. Filling voids in subterranean termite (Blattodea: Rhinotermitidae) bait stations with soil or clay improves preference and performance. Journal of Economic Entomology 111: 2303-2311 DOI 10.1093/jee/toy181.

Xiong H, Xue K, Qin W, Chen X, Wang H, Shi X, Ma T, Sun Z, Chen W, Tian X, Lin W, Wen X, Wang C. 2018b. Does soil treated with conidial formulations of Trichoderma spp. attract or repel subterranean termites? Journal of Economic Entomology 111: 808-816 DOI $10.1093 /$ jee/toy021. 


\section{Table 1 (on next page)}

Basic information about soil and clay used in the present study. 


\begin{tabular}{|c|c|c|c|c|c|c|c|c|c|c|c|c|}
\hline \multirow{2}{*}{ Clay / soil } & \multirow{2}{*}{ Clay mineral group } & \multirow{2}{*}{$\mathrm{PH}$} & \multirow{2}{*}{$\begin{array}{l}\text { Organic } \\
\text { matter } \\
\text { content } \\
(\mathrm{g} / \mathrm{kg})\end{array}$} & \multirow{2}{*}{$\begin{array}{l}\text { Total } \\
\text { nitrogen } \\
\text { content } \\
(\mathrm{g} / \mathrm{kg})\end{array}$} & \multicolumn{4}{|c|}{$\begin{array}{l}\text { Exchangeable cation content } \\
\qquad(\mathrm{cmol} / \mathrm{kg})\end{array}$} & \multirow{2}{*}{$\begin{array}{c}\mathrm{CEC}^{\mathrm{a}} \\
(\mathrm{cmol} / \mathrm{kg})\end{array}$} & \multicolumn{3}{|c|}{$\begin{array}{l}\text { Water absorption at each } \\
\text { water saturation }\end{array}$} \\
\hline & & & & & $\mathrm{K}^{+}$ & $\mathrm{Na}^{+}$ & $\mathrm{Ca}^{2+}$ & $\mathrm{Mg}^{2+}$ & & $100 \%{ }^{b}$ & $50 \%{ }^{\mathrm{b}}$ & $25 \%{ }^{b}$ \\
\hline Bentonite & $\begin{array}{l}\text { Montmorillonite/ } \\
\text { Smectite Group }\end{array}$ & 9.47 & 4.03 & 0.13 & 1.52 & 54.96 & 13.93 & 1.22 & 54.98 & $8.14^{c}$ & $4.07^{\mathrm{c}}$ & $2.03^{c}$ \\
\hline Kaolin & Kaolin Group & 9.74 & 0.46 & 0.02 & 0.03 & 0.06 & 5.86 & 3.33 & 1.00 & 0.70 & 0.35 & 0.17 \\
\hline Chlorite & Chlorite Group & 7.82 & 4.23 & 0.16 & 0.09 & 0.09 & 15.86 & 7.24 & 1.03 & 0.92 & 0.46 & 0.23 \\
\hline Illite & Illite Group & 8.09 & 2.02 & 0.23 & 3.73 & 0.30 & 0.49 & 0.13 & 5.35 & 1.09 & 0.55 & 0.27 \\
\hline Attapulgite & Palygorskite Group & 10.12 & 3.58 & 0.26 & 0.89 & 27.43 & 16.24 & 5.01 & 38.81 & 2.92 & 1.46 & 0.73 \\
\hline Soil & - & 4.83 & 13.48 & 0.60 & 0.04 & 0.01 & 0.16 & 0.03 & 5.55 & 0.41 & 0.20 & 0.10 \\
\hline
\end{tabular}

2

$3 \quad{ }^{a}$ CEC indicates cation exchange capacity.

$4 \quad{ }^{\mathrm{b}}$ Water saturation level.

$5{ }^{\mathrm{c}}$ Amount of deionized water $(\mathrm{g})$ can be absorbed by $1 \mathrm{~g}$ dry powder of clay to reach the $100 \%, 50 \%$, or $25 \%$ water saturation level. 
Table 2 (on next page)

Basic information of the three colony groups of Coptotermes formosanus used in the choice and no-choice tests. 


\begin{tabular}{|c|c|c|c|c|c|}
\hline \multirow{3}{*}{ Colony group } & \multirow{3}{*}{ Collection site } & \multicolumn{4}{|c|}{ Caste distribution ${ }^{a}(\%)$} \\
\hline & & \multicolumn{2}{|c|}{ Choice test } & \multicolumn{2}{|c|}{ No-choice test } \\
\hline & & Worker & Soldier & Worker & Soldier \\
\hline 1 & $23^{\circ} 09^{\prime} 37^{\prime \prime} \mathrm{N}, 113^{\circ} 21^{\prime} 30^{\prime \prime} \mathrm{E}$ & 99 & 1 & & \\
\hline 2 & $23^{\circ} 09^{\prime} 33^{\prime \prime} \mathrm{N}, 113^{\circ} 21^{\prime} 07^{\prime \prime} \mathrm{E}$ & 97 & 3 & 99 & 1 \\
\hline 3 & $23^{\circ} 09^{\prime} 34^{\prime \prime} \mathrm{N}, 113^{\circ} 21^{\prime} 08^{\prime \prime} \mathrm{E}$ & 94 & 6 & 96 & 4 \\
\hline
\end{tabular}

2

$3 \quad$ a The percentages of workers and soldiers in each colony group were determined by counting 100 termites for 5 4 times. The mean percentages are shown here and used to set the experiment. 
Figure 1

Coptotermes formosanus usually transports clay or soil into tree holes (A) and bait stations (B).

The first picture was taken by Wenquan Qin, and the second one was taken by Zhengya Jin. 

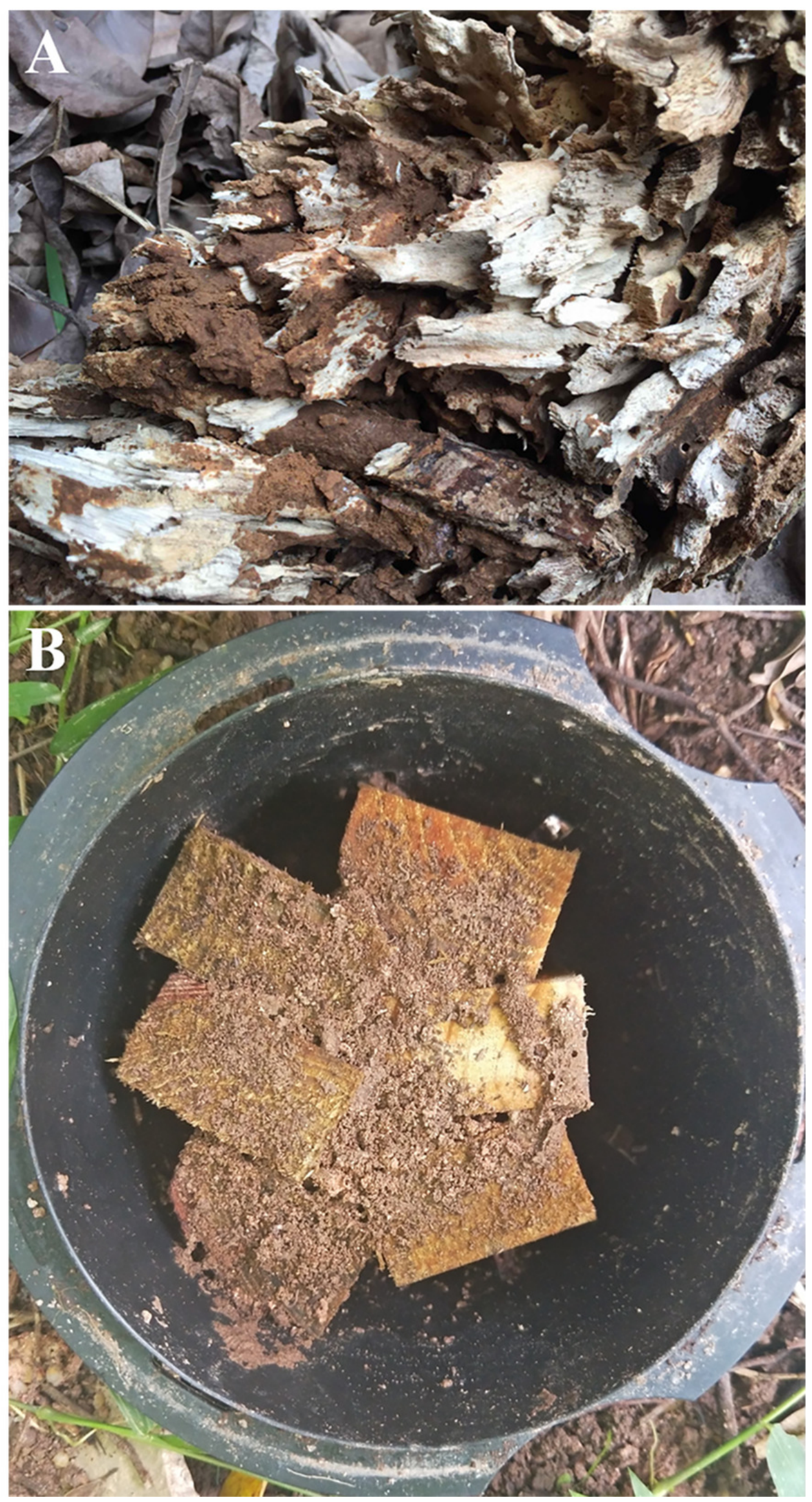


\section{Figure 2}

Procedures to set experiment 1.

Hollow space of wooden cylinders was either filled with the clay material (chlorite, attapulgite, bentonite, kaolin, or illite) or soil, or remained unfilled (A). Substrate (soil) was added into the container to the depth of $0.5 \mathrm{~cm}$, and seven wooden cylinders were placed on the substrate with randomly assigned orders. Additional substrate was then added until the base of cylinders was partially buried in the depth of $1 \mathrm{~cm}$ (B). Pictures were taken by Zhengya Jin. 


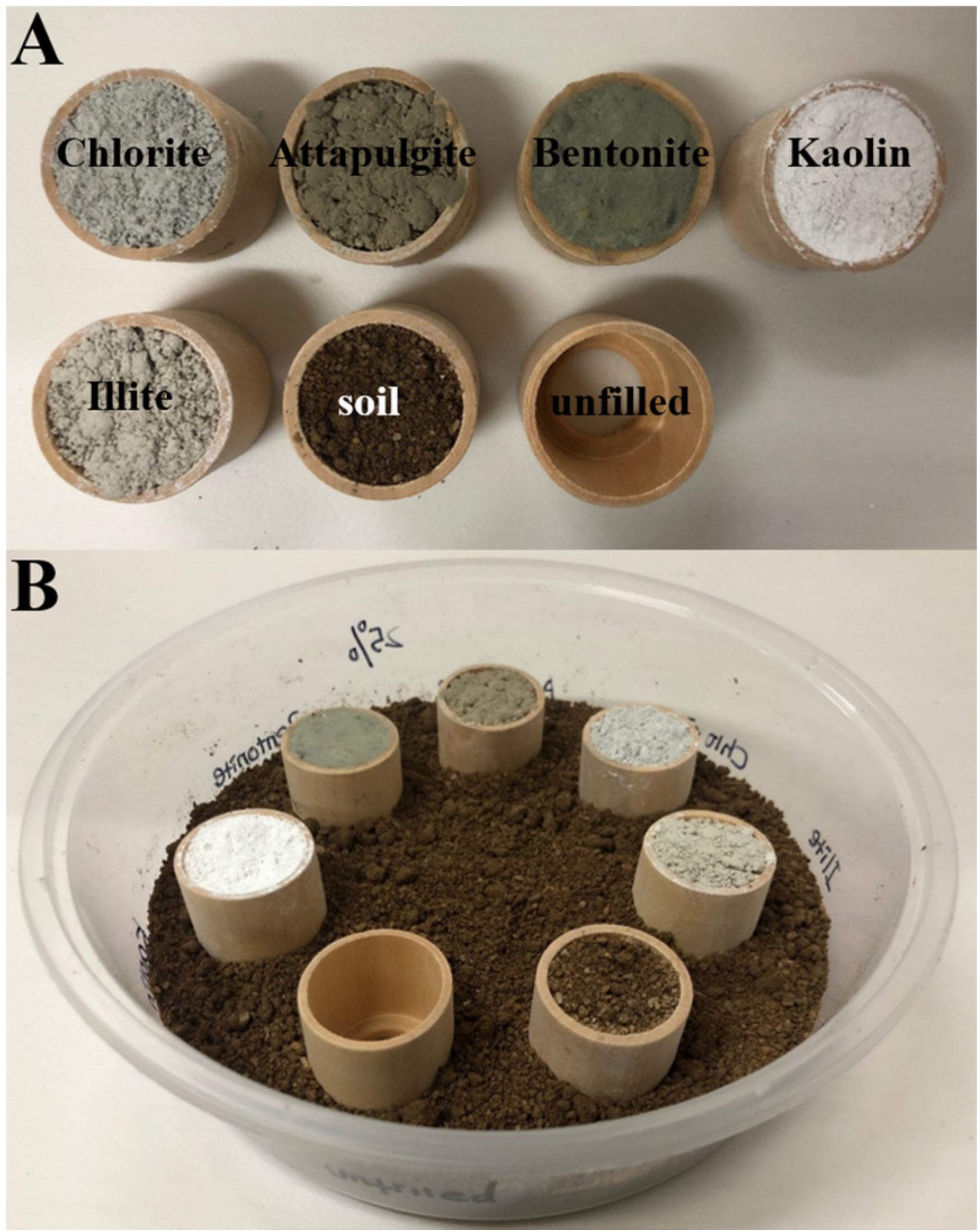




\section{Figure 3}

Procedures to set experiment 2 .

The baiting containers were prepared by drilling 10 holes on the wall of a plastic box and placing a wood block inside. Baiting containers was either remained unfilled (A), or filled with the clay material (bentonite, kaolin, chlorite, illite, or attapulgite) or soil (B). These baiting containers were then placed in the bioassay arenas with randomly assigned orders, and substrate (soil) was added until the baiting containers were buried (C). Pictures were taken by Zhengya Jin. 


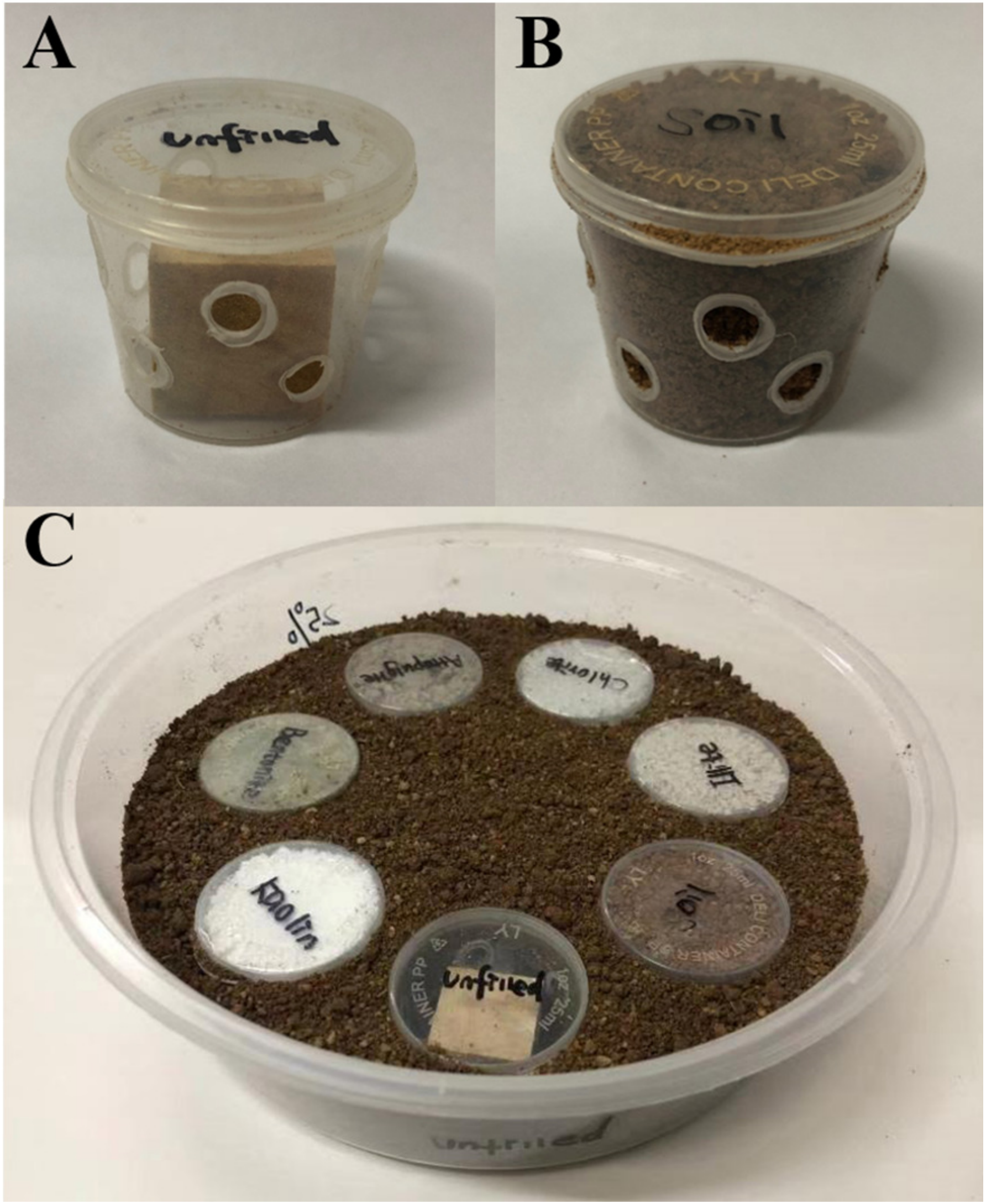


Figure 4

Results (mean $\pm \mathrm{SE}$ ) of experiment 1 (under low-moisture conditions) showing the percentage of termites in each location $(A)$ and consumption of wooden cylinders $(B)$.

Significant differences are indicated by different letters $(P<0.05)$.
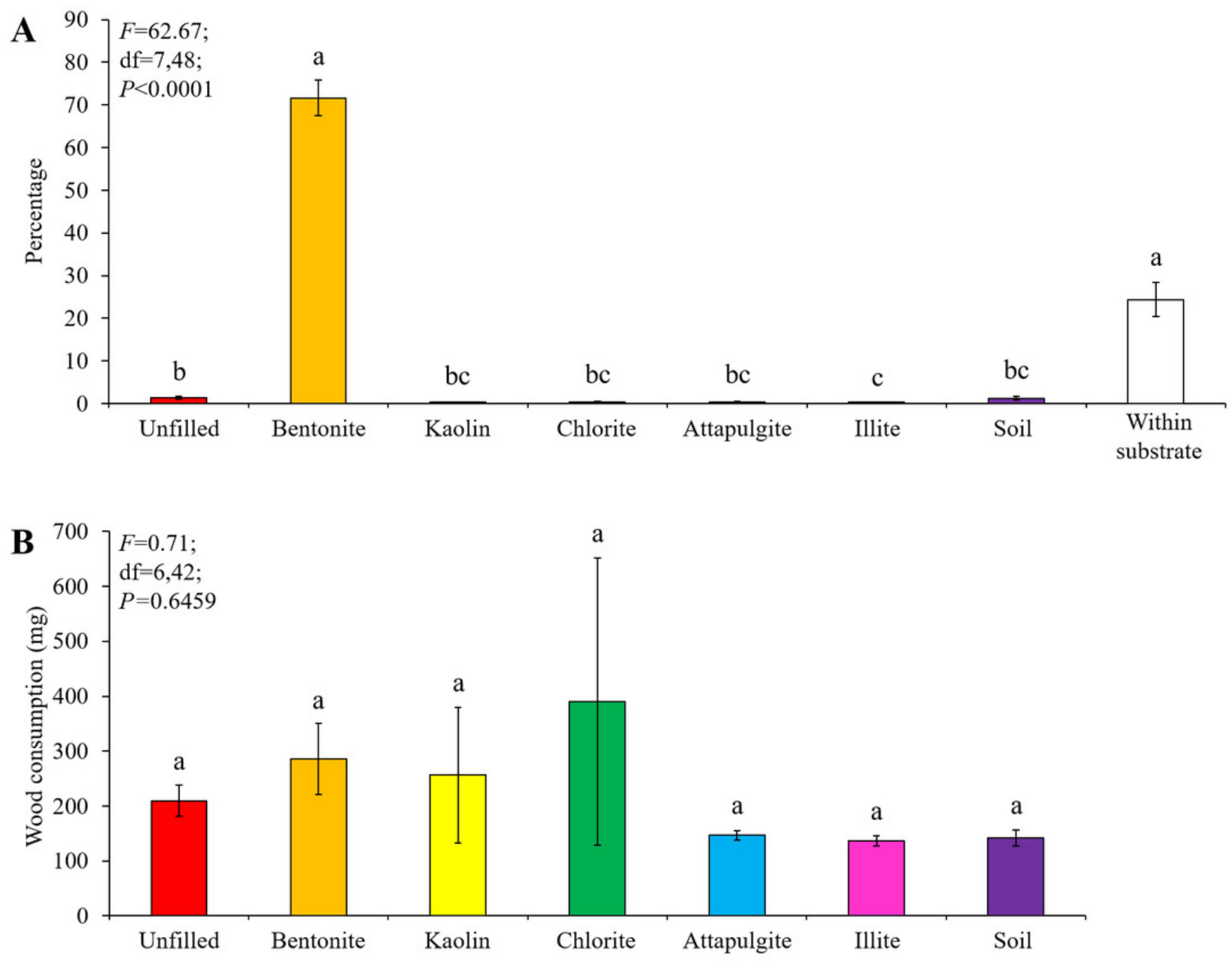
Figure 5

Results (mean $\pm \mathrm{SE}$ ) of experiment 1 (under moderate-moisture conditions) showing the percentage of termites in each location (A) and consumption of wooden cylinders (B).

Significant differences are indicated by different letters $(P<0.05)$.
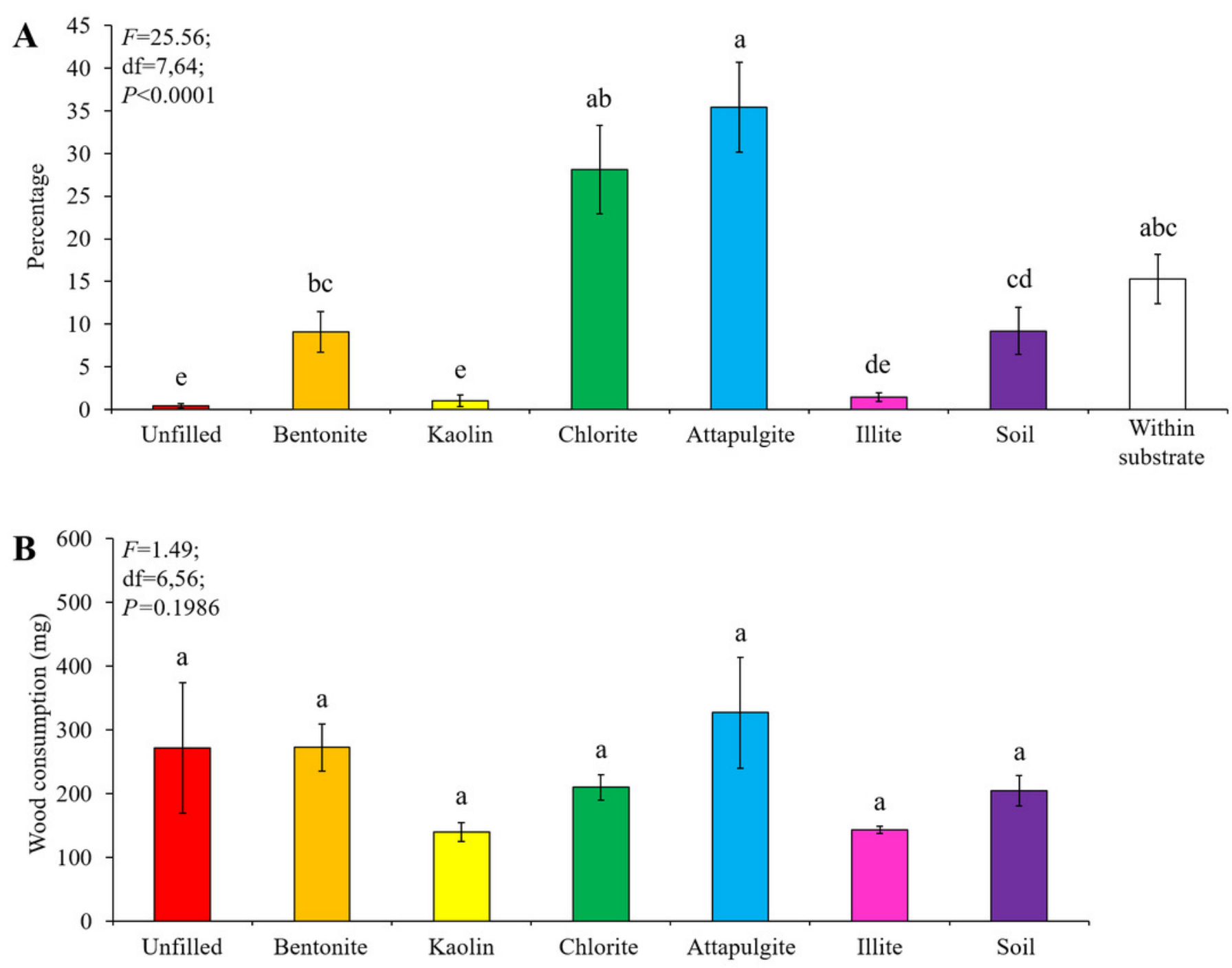
Figure 6

Results (mean $\pm \mathrm{SE}$ ) of experiment 2 (under low-moisture conditions) showing the percentage of termites in each location (A), and wood consumption (B) and wood moisture $(C)$ in each baiting container.

Significant differences are indicated by different letters $(P<0.05)$. 

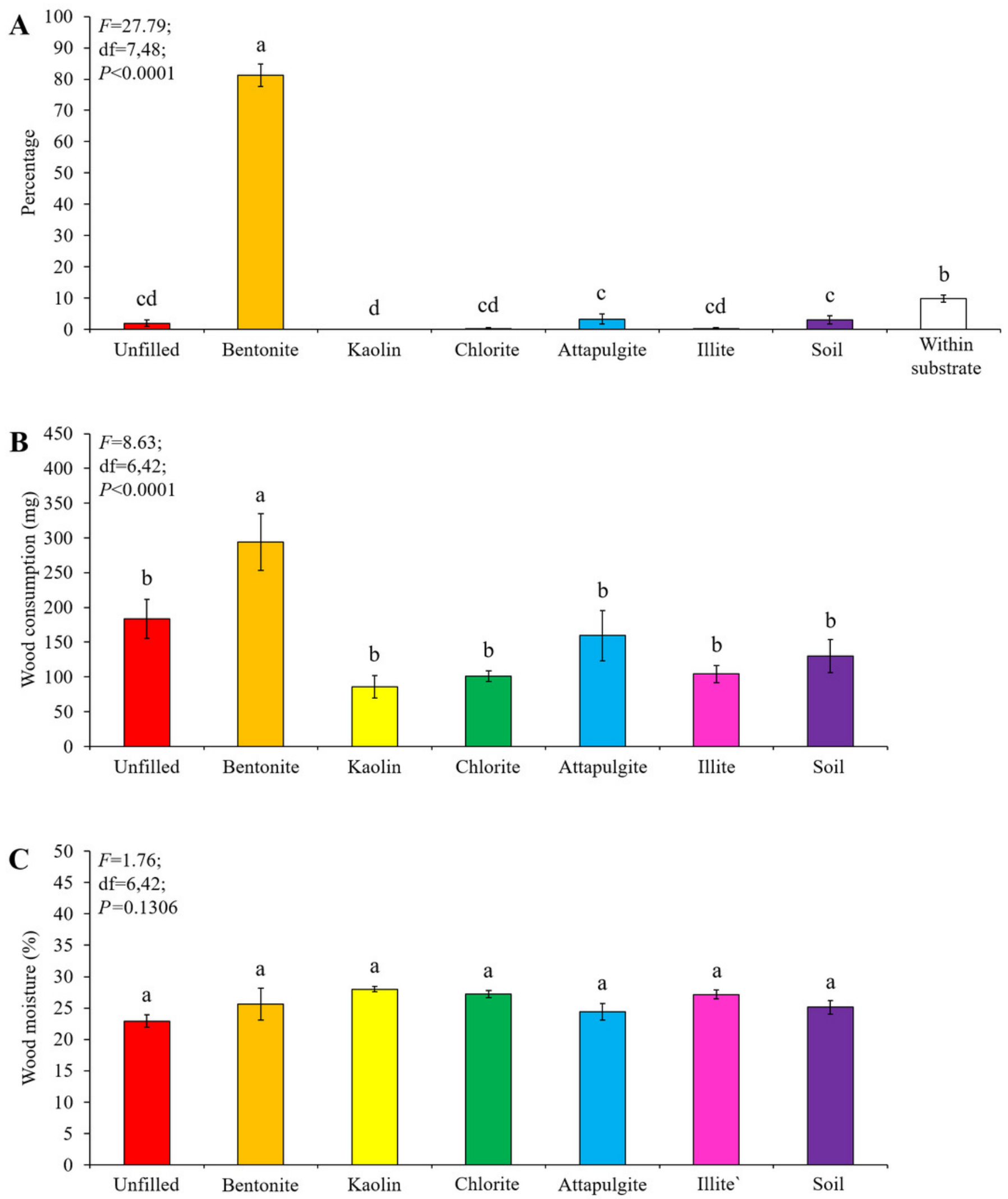


\section{Figure 7}

Results (mean $\pm \mathrm{SE}$ ) of experiment 2 (under moderate-moisture conditions) showing the percentage of termites in each location (A), and wood consumption (B) and wood moisture $(C)$ in each baiting container.

Significant differences are indicated by different letters $(P<0.05)$. 

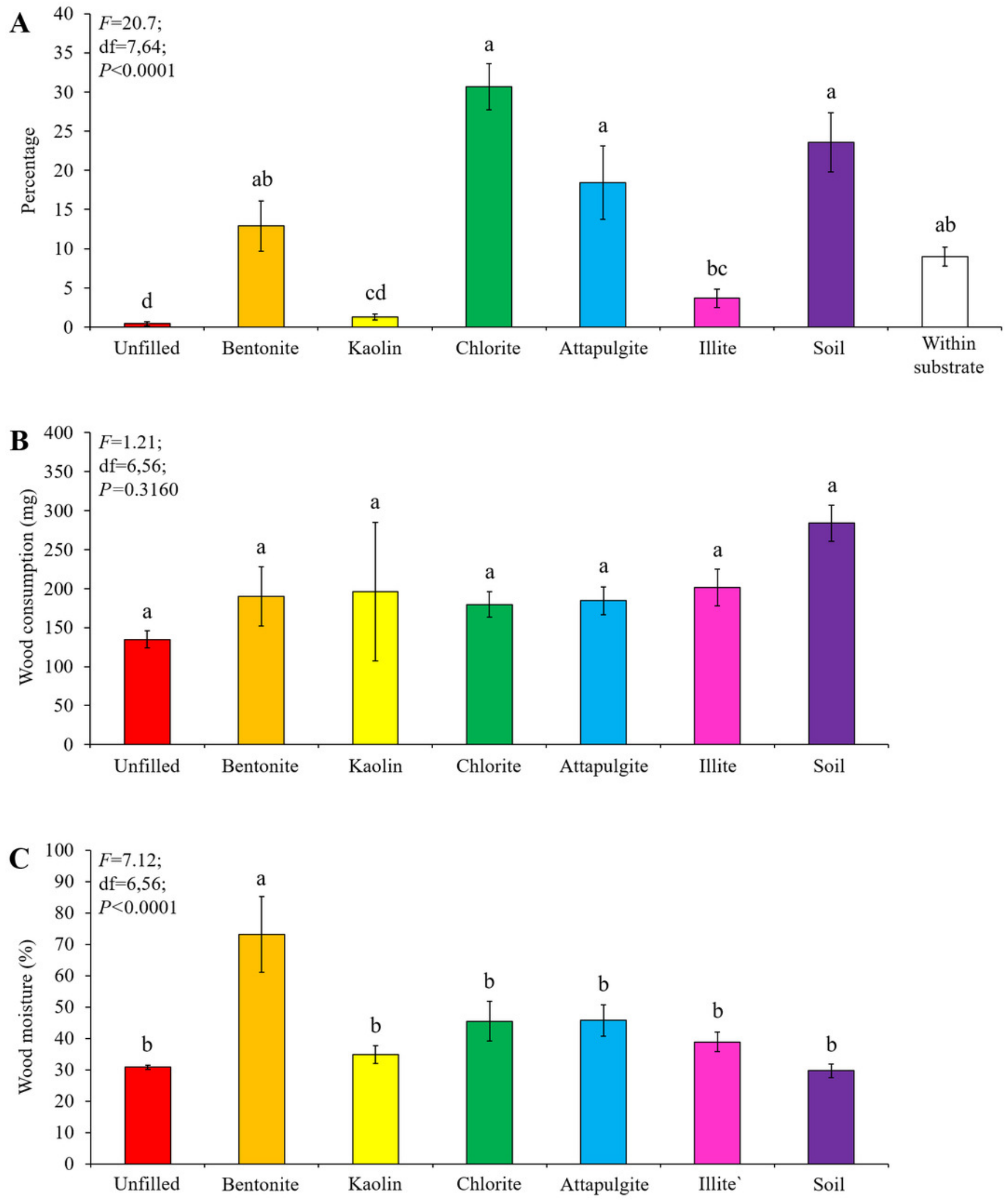
Figure 8

Results (mean $\pm \mathrm{SE}$ ) of experiment 3 showing the survivorship (A), body water percentage (B), and wood consumption (C) of termites, and wood moisture (D) in each treatment.

Significant differences are indicated by different letters $(P<0.05)$. 

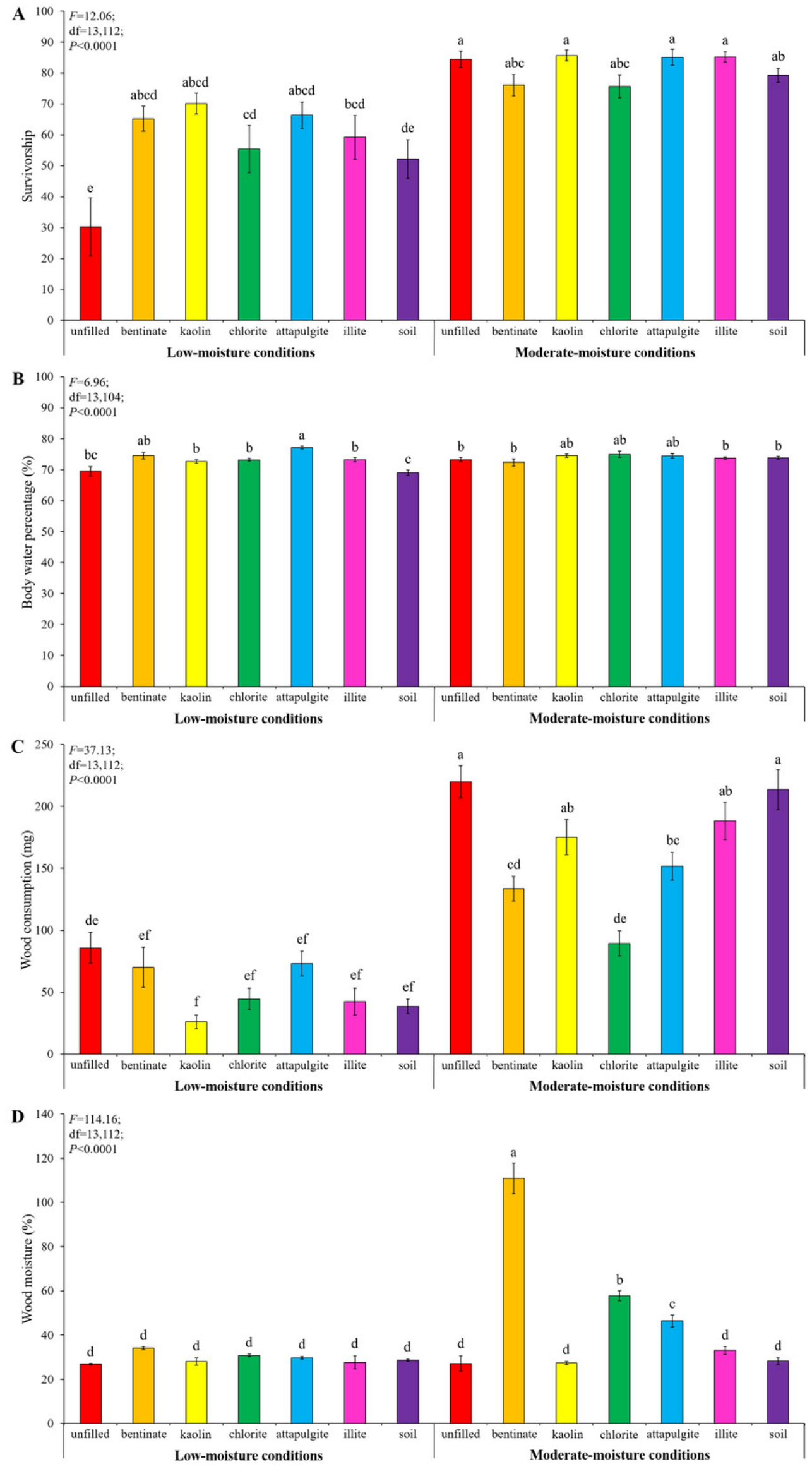